\title{
Utilization of Photosynthetically Produced Organic Particles by Dense Patches of Suspension Feeding Bivalves on the Sand Flat of Midori River Estuary, Kyushu, Japan
}

\author{
Hitomi Yamaguchi ${ }^{1)}$, Hiroaki Tsutsumi ${ }^{2)}$, Masanori Tsukuda ${ }^{2)}$, Sayaka Nagata ${ }^{2)}$, Chizuko Kimura ${ }^{2)}$, \\ Miho Yoshioka $^{2)}$, Seiichiro Shibanuma ${ }^{3)}$ and Shigeru Montani ${ }^{1)}$ \\ I) Graduate School of Fisheries Sciences, Hokkaido University, 3-I-I Minato, Hakodate, Hokkaido, 041-8611, Japan \\ 2) Faculty of Environmental and Symbiotic Sciences, Prefectural University of Kumamoto, \\ 3-1-100 Tsukide, Kumamoto, 862-0920, Japan \\ 3) CBEC Co., Ltd, 2-3-8-15 Tomioka, Teine, Sapporo, Hokkaido, 006-0012, Japan
}

\begin{abstract}
Midori River estuary faces Ariake Bay, and has the largest sandy tidal flat (approximately 2,100 ha) in Japan. We investigated the spatial distribution of particle size composition of the sediment, microphytobenthos on the surface sediment and macrobenthic animals at the stations set along a cross transect line in Midori River estuary. The Chl- $a$ concentrations of the surface sediment that reflected the biomass of the microphytobenthos ranged between 19.3 and $113 \mathrm{mg} / \mathrm{m}^{2}$ at the stations on the tidal flat, and tended to decrease from the upper part to the lower part of the tidal flat and the offshore area. However, $92.0 \%$ of the total biomass of the macrobenthic animals collected at the sampling stations on the tidal flat was concentrated at the stations on the middle to lower part of the tidal flat. The highest biomass reached $3,760 \mathrm{~g} \mathrm{WW} / \mathrm{m}^{2}$, mainly due to the occurrence of dense patches of two suspension feeding bivalves, Ruditapes philippinarum and Mactra veneriformis. These two bivalves alone occupied $93.2 \%$ of the biomass of all the benthic animals collected at all sampling stations. The consumption of the primarily produced organic matter estimated from the secondary production of only a single species of Ruditapes apparently exceeded the potential primary production at the same place. The results of this study suggest that the re-suspension of primarily produced organic particles by the microphytobenthos on "the upper part" of the tidal flat and its lateral transportation to "the middle to lower part" of the tidal flat is essential to sustain the high secondary production of the suspension feeding benthic bivalves on the middle to lower part of this tidal flat.
\end{abstract}

Key words: estuary, lateral transportation, Mactra veneriformis, microphytobenthos, Ruditapes philippinarum, suspension feeders, tidal flat

\section{INTRODUCTION}

Tidal flats are located on the transitional areas between land and sea, and are defined as the region of broad foreshore between the highest and lowest tides. The water depth of the tidal flats and near shore subtidal areas is so shallow (only a few meters) even at high tide that enough intensity of light for photosynthesis tends to reach the sediment surface. Therefore, on the tidal flats, not only the phytoplankton in the water column but also

Reccived Nov. 20, 2004: Accepted Dec. 28, 2004 the sediment-associated microalgae (microphytobenthos) is able to become one of the major primary producers by photosynthesis (Underwood \& Kromkamp 1999). MacIntyre et al. (1996) noted that the primary production of the microphytobenthos often exceeded that of the phytoplankton in the water column on the tidal flats. In previous studies on Japanese coast, Montani et al. (2003) reported the primary production by the microphytobenthos on a tidal flat of the Seto Inland Sea $\left(434 \mathrm{~g} \mathrm{C} / \mathrm{m}^{2} / \mathrm{yr}\right)$, western Japan, was approximately two times higher than that by the phytoplankton in the water column offshore from the tidal flat.

On the tidal flats, foods are ample for the macrobenthic animals due to high primary productivity on the sedi- 
ment surface and in the water column. Moreover, the surface layer of the sediment is always kept in oxidized conditions owing to periodic air exposure during low tide. Such characteristics of the environmental conditions on the tidal flats allow the macrobenthic animals to exploit the ample food resources and establish dense patches (Sasaki 1994). Akiyama \& Matsuda (1974) reviewed the previous studies on the occurrence of the macrobenthic animals on the tidal flats in Japanese coasts, and showed that the mean biomass of the macrobenthic animals on the tidal flats $\left(293 \mathrm{~g} \mathrm{WW} / \mathrm{m}^{2}\right)$ was approximately five times larger than that of the subtidal areas in the coastal seas.

In the coastal ecosystem including the tidal flats, numerous attempts have been made to describe the conversion of organic matter between the primary (photosynthetic) producers and the secondary ones, estimating their productive activities (Graf et al. 1982; Loo \& Rosenberg 1988; Graf 1992). However, as in the case of the macrobenthic communities where suspension feeding animals predominate as secondary producers, the consumption by the suspension feeders tends to exceed the primary production at the areas where the suspension feeders occur (Heip et al. 1995; Herman et al. 1999; Thompson \& Schaffner 2001). Loo \& Rosenberg (1996) reviewed the pelagic (phytoplanktonic) primary production and the secondary production of the suspension feeding benthic animals in the coastal areas of Skagerrak and Kattegat, Sweden, and reported that the annual secondary production of only two suspension feeding bivalves, Cerastoderma edule and Mya arenaria, in the Gullmars fjord reached $11,094 \mathrm{~kJ} / \mathrm{m}^{2} / \mathrm{yr}$, which was almost equivalent to the pelagic primary production of these areas. If we assume the ecological trophic transfer efficiency between different trophic levels as 15\% (Ryther 1969), primary production at least six times higher than pelagic production should be required to sustain the secondary production of these two dominant bivalves. Therefore, Loo \& Rosenberg (1996) emphasized the importance of the intake of organic particles transported from other neighboring areas by the tidal current to allow the suspension feeding benthic animals to establish their dense patches. Thus, to understand the mechanisms of the secondary production by the populations of the suspension feeding benthic animals, we need to know how they obtain the (primarily) photosynthetically produced organic particles from the water.

Our study area, Midori River estuary, is located on the east coast of Ariake Bay, in the western part of the Kyushu Island, Japan. It has the largest sand flat $(2,100$ ha) in Japan. On the tidal flat of this estuary, sus- pension feeding bivalves Ruditapes philippinarum, Mactra veneriformis and Solen strictus are some of the dominant species of the macrobenthic communities. They often occupy more than $95 \%$ of the biomass of the macrobenthic animals (Tsutsumi et al. 2000). Tsutsumi et al. (2002) investigated the population dynamics of $R$. philippinarum on the lower part of this tidal flat, and estimated its secondary production as $93.6 \mathrm{~g} \mathrm{C} / \mathrm{m}^{2} / \mathrm{yr}$. According to Heip et al. (1995), the annual secondary production of macrobenthic communities observed at various estuaries ranged from 1.2 to $273 \mathrm{~g} \mathrm{AFDW} / \mathrm{m}^{2} / \mathrm{yr}$. These values are equivalent to 0.4 to $98.3 \mathrm{gC} / \mathrm{m}^{2} / \mathrm{yr}$ with a carbon/AFDW ratio of 0.36 (Nagao et al. 2000). On the lower part of Midori River Mouth Tidal Flat, the secondary production of just a single species of $R$. philippinarum is equivalent to the highest values of the secondary production of the benthic communities recorded in the previous studies. Therefore, it is an interesting question how such a high secondary production of the suspension feeding bivalve, $R$. philippinarum, is nutritionally supported by the primary production on this tidal flat.

In this paper, we focus on how the suspension feeding bivalve, $R$. philippinarum, obtains the (primarily) photosynthetically produced organic particles on the lower part of Midori River Mouth Tidal Flat. We report the spatial distribution of the microphytobenthos as some of the main primary producers on the tidal flat and the macrobenthic animals at the sampling stations set along a cross transect line on Midori River estuary, and discuss the importance of lateral transportation of primarily produced organic particles re-suspended in the water from the sediment surface to sustain the secondary production of Ruditapes population on the tidal flat.

\section{MATERIALS AND METHODS}

\section{Study area}

The study area was Midori River estuary, on the east coast of Ariake Bay, Kumamoto, Japan (Fig. 1). This study area has large tidal amplitudes of approximately $5 \mathrm{~m}$ in spring tide. During the low tide, a large tidal flat, Midori River Mouth Tidal Flat, appear with the area of 2,100 ha (Environmental Agency, Japan 1994) and $4.5 \mathrm{~km}$ in length from the shore to the seaward end of the tidal flat.

We set 21 stations (Stn 1-21) along a transect line extending from the inshore to the offshore (Fig. 1). Stn 1 to 16 were located on the tidal flat with approximately $250 \mathrm{~m}$ intervals. From Stn 17 to 21 were located offshore from the tidal flat with approximately $1 \mathrm{~km}$ intervals. In 


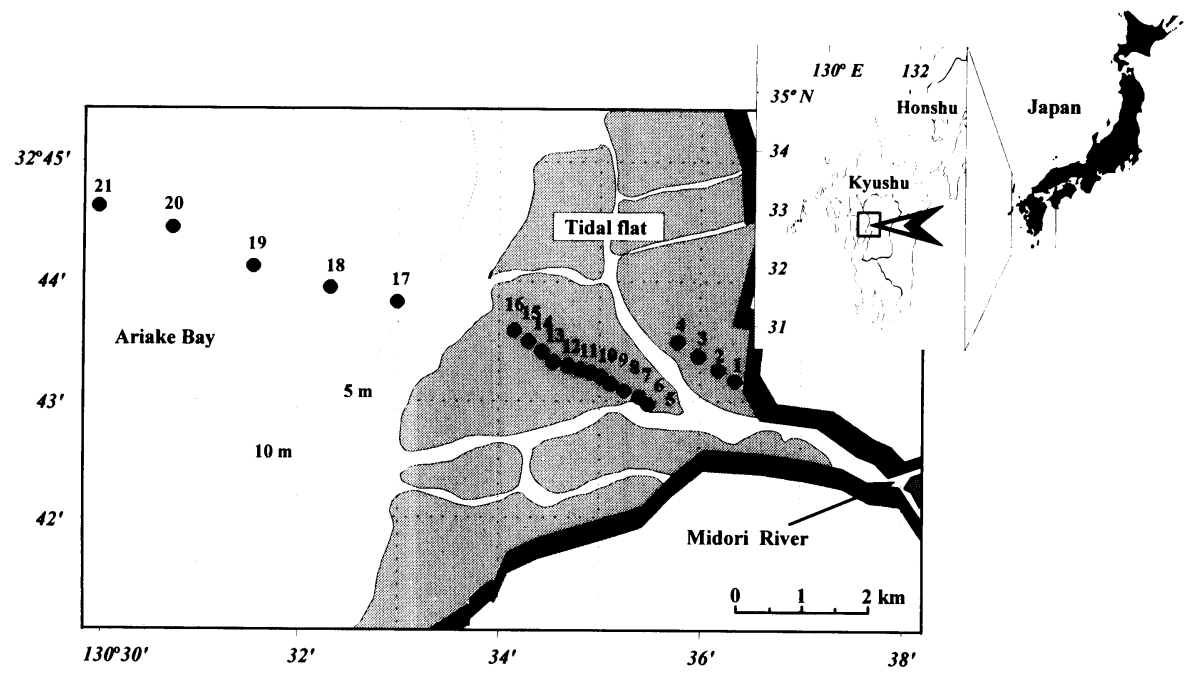

Fig. 1. The geographical location of Midori River estuary and the sampling stations in this study.

this paper, we refer to Stn 1 to 7 as "the upper part of the tidal flat", Stn 8 to 16 as "the middle to lower part of the tidal flat", and Stn 17 to 21 as "the subtidal area".

\section{Sampling methods and analysis}

We conducted surveys of the environmental conditions and sampling of the macrobenthic animals at sixteen stations (Stn 1 to 16) on the tidal flat on Sep. 6, 2002, and at five stations (Stn 17 to 21) on the subtidal area from a boat on Sep. 7, 2002. During the low tide, at each station on the tidal flat, we collected five core samples of the sediment for chemical analysis with an acrylic core sampler ( $3 \mathrm{~cm}$ in diameter; see Montani et al. 2003). The surface layer of the sediment up to $1 \mathrm{~cm}$ in depth was used for the analysis. We also collected a core sample of the sediment for determining the particle size composition and five core samples for examining the abundance and biomass of the macrobenthic animals with a handheld steel core sampler $(10 \times 10 \times 5 \mathrm{~cm})$. At each station in the subtidal area, we collected five core samples of the sediment for chemical analysis with a K.K. type gravity core sampler (4 cm in diameter; see Kimata et al. 1960). The surface layer of the sediment up to $1 \mathrm{~cm}$ in depth was used for the analysis. We also collected a sample of the sediment for determining the particle size composition and five samples for examining the abundance and biomass of the macrobenthic animals with an Ekman-Birge grab sampler $(20 \times 20 \mathrm{~cm})$.

Particle size composition of the sediment was determined by the wet sieving method. For the determination of the contents of total organic carbon (TOC) and total nitrogen (TN) of the sediment, the sediment samples were freeze-dried, treated with $2 \mathrm{~N}$ hydrochloric acid to remove carbonates, and determined with an elemental analyzer (Faisons, NA-1500). For the determination of the contents of Chlorophyll $a$ (Chl-a) and pheo-pigments of the sediment, the wet sediment samples were soaked with 90\% acetone, and the concentrations of Chlorophyll $a$ and pheo-pigments of their supernatants were determined by the fluorometric method (Yentsch \& Menzel 1963) using a fluorometer (Turner designs, 10-AU).

The sediment samples for the quantitative surveys of the macrobenthic animals were sieved on a $1 \mathrm{~mm}$ mesh sieve. The residues retained on the sieve were fixed and stained with $10 \%$ formalin solution and a dye, Rose Bengal. The macrobenthic animals were sorted from the residues, and their species identified using a stereoscopic microscope. The number of the individuals of each species was counted. After removing the water of the specimen with a blotting paper, the wet weight of each species was measured.

\section{RESULTS}

\section{Particle size composition of the sediment}

Fig. 2 indicates the particle size composition of the sediment at each station. On the tidal flat, the particle size composition of the sediment showed a clear spatial distribution pattern from the shore to the offshore. The sediment on the upper end of the tidal flat (Stn 1) was mainly consisted of mud (finer than $63 \mu \mathrm{m}$ in diameter) and very fine sand (63 to $125 \mu \mathrm{m}$ in diameter). These two fractions accounted for $84.5 \%$ of the weight of the whole sediment. The fractions of the mud and very fine sand of the 


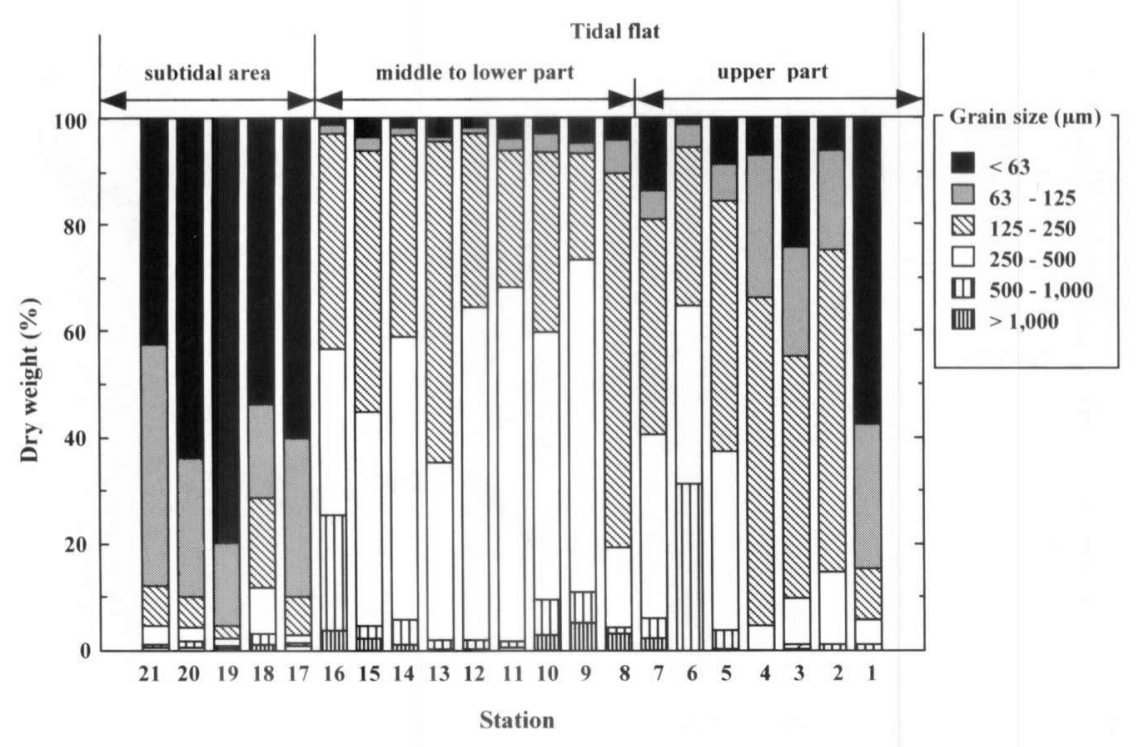

Fig. 2. Particle size composition of the sediment at each station.

sediment tended to markedly decrease toward the lower end of the tidal flat (Stn 16). On the middle to lower part of the tidal flat, the sediment contained only 2.8 to $10.5 \%$ of these two fractions, respectively. The sediment of this area was mainly consisted of fine sand (125 to $250 \mu \mathrm{m}$ in diameter) and medium sand ( 250 to $500 \mu \mathrm{m}$ in diameter), 71.7 to $94.9 \%$ of the weight of the whole sediment. At the subtidal area, the contents of the mud and very fine sand drastically increased again. These two fractions occupied 71.4 to $95.4 \%$ of the weight of the whole sediment.

Chemical composition of organic matter of the sediment

Fig. 3 shows the relationship between the percentage of the mud and very fine sand in the weight of the whole sediment and the organic matter content of the sediment with (a) TOC and (b) TN. Significant positive correlations were found in both of these two relationships (a: $\mathrm{F}$ test, $\mathrm{p}<0.001, \mathrm{~b}: \mathrm{F}$ test, $\mathrm{p}<0.001$ ). The sediment with higher content of the mud and very fine sand tended to retain higher organic matter content.

Fig. 4 illustrates the contents of TOC and TN of the sediment at each sampling station. These values reflected well the contents of the fine particles of the sediment at each station (Fig. 3). As the fractions of the mud and very fine sand of the sediment markedly decreased from the upper part to the lower part of the tidal flat, the contents of TOC and TN of the sediment also decreased. The mean contents of TOC and TN of the sediment on the upper part of the tidal flat was $3.41 \pm 2.50 \mathrm{mg} / \mathrm{g}$
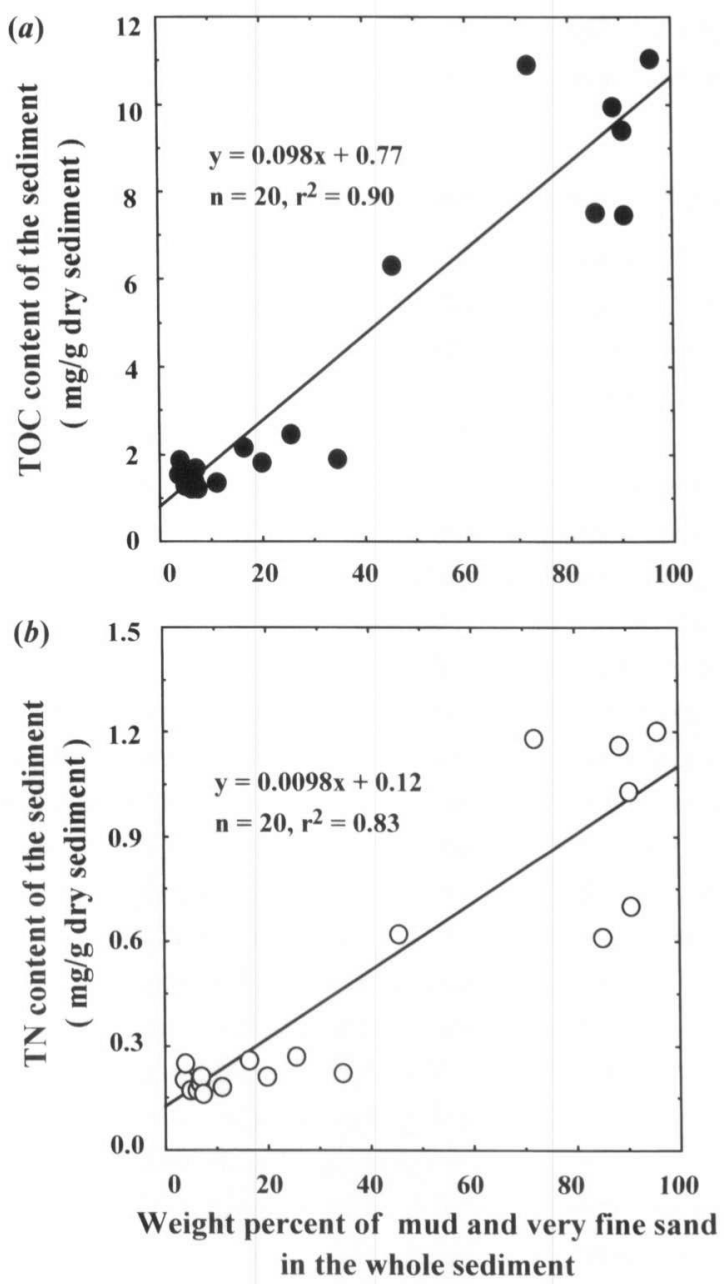

Fig. 3. The relationship between the proportions of mud and very fine sand (the particles finer than $125 \mu \mathrm{m}$ in diameter) in the whole sediment and (a) TOC content of the sediment and (b) TN content of the sediment. 


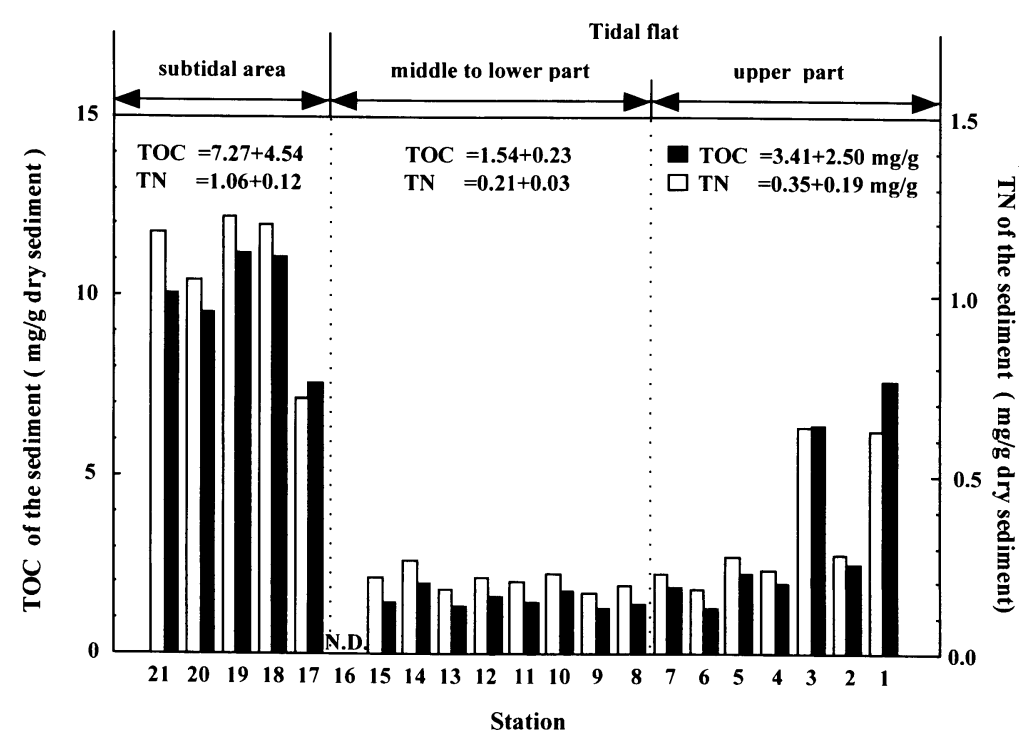

Fig. 4. TOC and TN content of the sediment. N.D. indicates not determined.

(mean \pm S.D.) and $0.35 \pm 0.19 \mathrm{mg} / \mathrm{g}$, respectively. On the middle to lower part of the tidal flat, both of them were less than half of those on the upper part, $1.54 \pm 0.23 \mathrm{mg} / \mathrm{g}$ and $0.21 \pm 0.03 \mathrm{mg} / \mathrm{g}$, respectively. At the subtidal area, the sediment contained high proportion of the mud and very fine sand ( 71.4 to $95.4 \%$ ), and the highest organic matter contents of the sediment were recorded. The mean content of TOC and TN of the sediment was 7.27 \pm 4.54 $\mathrm{mg} / \mathrm{g}$ and $1.06 \pm 0.12 \mathrm{mg} / \mathrm{g}$, respectively.

\section{Photosynthetic pigment concentrations of the surface sediment}

Fig. 5(a) shows both Chl- $a$ and pheo-pigments concentration of the sediment at each sampling station. The extremely high Chl- $a$ concentrations of the sediments were observed at Stn $2\left(75.3 \mathrm{mg} / \mathrm{m}^{2}\right)$ and $\operatorname{Stn} 3(113$ $\mathrm{mg} / \mathrm{m}^{2}$ ) on the upper part of the tidal flat. Excluding these two stations, they ranged between 19.3 and $35.3 \mathrm{mg} / \mathrm{m}^{2}$, and tended to decrease toward the lower end of the tidal flat. At the subtidal area, the Chl- $a$ concentration of the sediment further decreased to the range between 9.81 and $21.5 \mathrm{mg} / \mathrm{m}^{2}$.

No clear trends were found in the spatial distribution pattern of pheo-pigments concentration of the sediment along the transect line on the tidal flat. The highest concentration of the pheo-pigments was observed at Stn $14\left(138 \mathrm{mg} / \mathrm{m}^{2}\right)$, but the lowest value was observed at the neighboring station, Stn $13\left(25.5 \mathrm{mg} / \mathrm{m}^{2}\right)$. At the subtidal area, pheo-pigments concentrations in the sediments were high at all five stations, ranging between 74.1 and $136 \mathrm{mg} / \mathrm{m}^{2}$, although the sediments had the lowest levels of Chl- $a$ concentrations.

Pheo-pigments are produced by the decomposition of fresh photosynthetic pigments such as chlorophylls. If the organic matter photosynthetically produced by the microphytobenthos on the sediment surface was consumed in the same area, the concentration of the pheopigments of the sediment at each station should strongly correlate to that of the Chl- $a$ of the sediment. However, the spatial distribution patterns of the concentration of these two photosynthetic pigments of the sediment did not necessarily coincide (Fig. 5(b)). At Stn 2 and 3 on the upper part of the tidal flat, where the highest Chl- $a$ concentrations of the sediments were recorded, the weight ratios of Chl- $a$ to the whole photosynthetic pigments (Chl- $a$ and pheo-pigments) of the sediment were also highest among all sampling stations on the tidal flat $(0.51$ and 0.49 , respectively). However, the ratio tended to decrease on the middle to lower part of the tidal flat, ranging between 0.18 and 0.51 , and showed the lowest values between 0.12 and 0.15 at the stations of the subtidal area.

\section{Density and biomass of the macrobenthic animals}

Fig. 6(a) illustrates the densities of dominant species of the macrobenthic animals at each sampling station. The data on the numerical composition of the macrobenthos are noted in the Appendix Table 1.

On the upper part of the tidal flat, the density of the macrobenthic animals was relatively low with the range between 120 and $840 \mathrm{ind} . / \mathrm{m}^{2}$. The suspension feeding bivalve, Mactra veneriformis was the most dominant, and the second ranked one was a surface deposit-feeding 

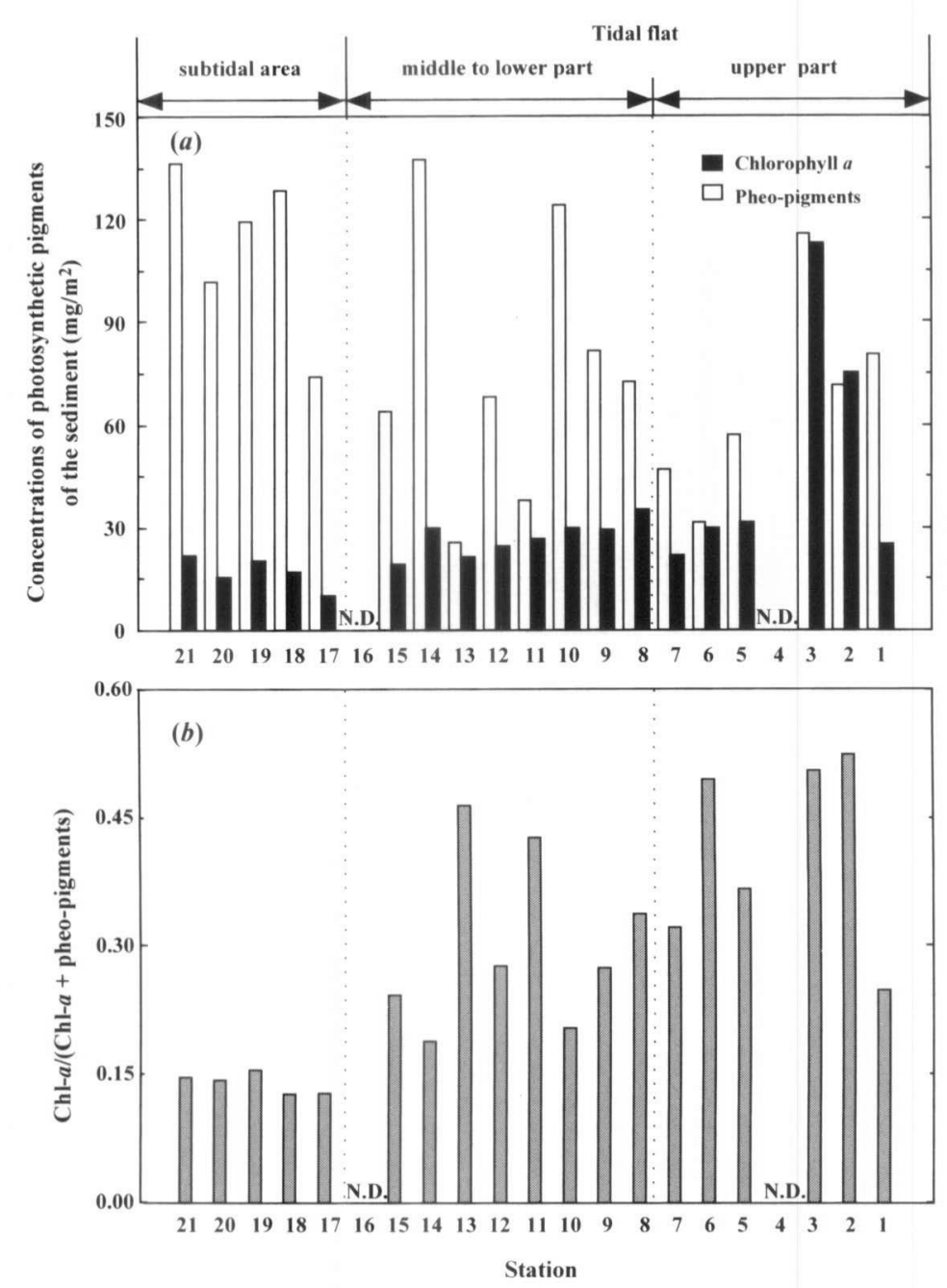

Fig. 5. (a) Chl- $a$ and pheo-pigments concentration of the sediment and (b) the weight ratio of Chl- $a$ to the whole photosynthetic pigments (Chl- $a$ and pheo-pigments) of the sediment at each station. N.D indicates not determined.

polychaete, Heteromastus cf. similes. They occupied $28.4 \%$ and $12.8 \%$ of the total numerical composition of the macrobenthic animals on this part, respectively.

On the middle to lower part of the tidal flat, extremely high densities were found at Stn $10(2,300$ ind. $\left./ \mathrm{m}^{2}\right)$ and $\mathrm{Stn} 14\left(2,280\right.$ ind. $\left./ \mathrm{m}^{2}\right)$ due to the occurrence of dense patches of $R$. philippinarum, the most dominant species on this part. At these two stations, it occupied $58.3 \%$ and $81.6 \%$ of the whole density of the macrobenthic animals, respectively. Except at these two stations, the densities ranged between 560 and $1,180 \mathrm{ind} . / \mathrm{m}^{2}$. The second ranked dominant species was also a suspension feeding bivalve, $M$. veneriformis. It occupied $15.2 \%$ of the total numerical composition of the macrobenthic animals on this part. Thus, on the middle and lower part of the tidal flat, suspension feeding bivalves predominated in the macrobenthic communities.

At the subtidal area, the highest density at all of the sampling stations, 2,800 ind./m², was recorded at Stn 19. At the other remaining four stations of subtidal area, the densities are relatively high, 864 to $1,980 \mathrm{ind} . / \mathrm{m}^{2}$. The most dominant species at all of the five stations was a small bivalve, Pillucina pisidium. It occupied $70.0 \%$ of the total numerical composition of the macrobenthic animals at the subtidal area.

Fig. 6(b) illustrates the biomass of macrobenthic animals, expressed by wet weight, at each station. The highest biomass values were observed at Stn 10 $\left(3,760 \mathrm{~g} \mathrm{WW} / \mathrm{m}^{2}\right)$ and $\operatorname{Stn} 14\left(2,342 \mathrm{gWW} / \mathrm{m}^{2}\right)$ on the middle to lower part of the tidal flat, where the suspension feeding bivalve, $R$. philippinarum occurred at high density. Excluding these two stations, the biomass of the macrobenthic animals on the middle to lower part of the tidal flat was in the range between 463 and $1,107 \mathrm{gWW} / \mathrm{m}^{2}$. The two dominant bivalves ( $R$. philippinarum and $M$. veneriformis) occupied $93.5 \%$ of the 

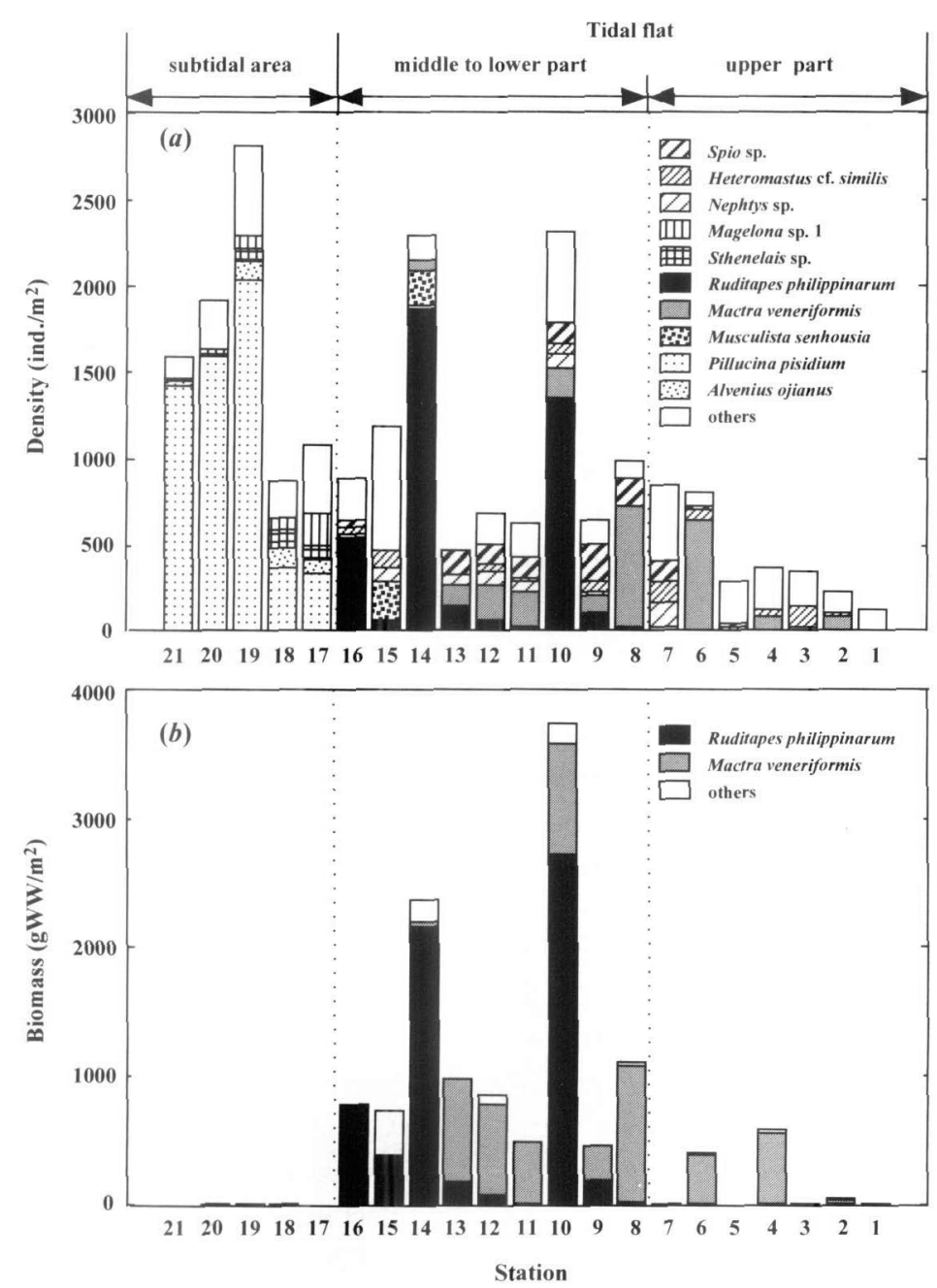

Fig. 6. (a) Density and (b) biomass of the macrobenthic animals at each station.

total biomass on this part of the tidal flat and $93.2 \%$ of the total biomass at all sampling stations. At the subtidal area, in spite of the occurrence of a bivalve, $P$. pisidium, in high densities $\left(330-2,030 \mathrm{ind} . / \mathrm{m}^{2}\right)$, the total biomass of the macrobenthic animals was extremely low (4.4 to $11.6 \mathrm{~g} \mathrm{WW} / \mathrm{m}^{2}$ ). Consequently, $92.0 \%$ of the biomass of the macrobenthic animals collected from all sampling stations in Midori River estuary was concentrated on the middle to lower part of the tidal flat.

\section{DISCUSSION}

\section{Spatial difference of the physico-chemical character- istics of the sediment}

The particle size composition of the sediment showed a clear spatial gradient (Fig. 2). The fractions of the mud and very fine sand (finer than $125 \mu \mathrm{m}$ in diameter) in the total sediment markedly decreased from the upper end ( $\operatorname{Stn} 1,84.5 \%$ ) to lower end of the tidal flat (Stn 16, 2.8\%). On the other hand, these two fractions occupied high proportions at the subtidal area (Stn 17-21, 71.4-95.4\%) such as Stn 1 located on the uppermost areas of the tidal flat. There was a significant positive relationship between the fractions of the fine particles of less than $125 \mu \mathrm{m}$ in diameter and TOC and TN contents of the sediment (Fig. 3). Consequently, the organic matter content of the sediment showed a clear spatial distribution pattern as the fraction of the mud and very fine sand of the sediment (Fig. 4).

Such distribution patterns of the fine particles and the organic matter content of the sediment area offshore from the tidal flat are caused by deposition of the sediment supplied from the river on the tidal flat, re-suspension of only the fine particles with high organic matter content and lateral transportation of the fine particles to the upper part of the tidal flat and to the subtidal area offshore from the tidal flat by the tidal current (Saijyo \& 
Okuda 1996). In Midori River estuary, the tidal amplitude reaches approximately $5 \mathrm{~m}$ in spring tide, which is the largest on the Japanese coast. This big tidal difference generates a very first tidal current over $30 \mathrm{~cm} / \mathrm{sec}$ even in the benthic boundary layer (unpublished data). Therefore, the water on the tidal flat always becomes turbid due to re-suspension of the fine fractions of the sediments with high organic matter contents.

Conover \& Durvasula (1986) reported that Chl-a was destroyed during the passage through the gut of herbivores, and decomposed to pheo-pigments such as pheophorbide- $a$. In this study, at Stn 2 and 3 on the upper part of the tidal flat, the concentration of Chl- $a$ of the surface sediment was highest $\left(75.3\right.$ and $113 \mathrm{mg} / \mathrm{m}^{2}$, respectively) among all of the sampling stations, and tended to decrease toward the lower one and offshore area (Fig. $5(\mathrm{a})$ ). The weight ratio of $\mathrm{Chl}-a$ to the total photosynthetic pigments including Chl- $a$ and pheo-pigments of the sediment showed the same tendency as the concentration of Chl- $a$ of the surface sediment. It was highest at Stn 2 and 3 ( 0.51 and 0.49 , respectively) on the upper part of the tidal flat, but tended to decreased toward the lower part and offshore area (Fig. 5(b)). These facts indicate the photosynthetic productive activities by the microphytobenthos were most active on the upper part of the tidal flat, and the decomposition of the photosynthetically produced organic particles was more prominent on the middle to lower tidal flat and the offshore area.

\section{Organic carbon flow from primary producers to ben- thic suspension feeders}

De Jong \& de Jong (1995) noted that the Chl- $a$ in the top layers of the estuarine sediment is derived mainly from microphytobenthos, which is one of the main food sources for the suspension feeding benthic animals. Koike et al. (1989) investigated the algal species composition in the stomach content of the macrobenthic animals found on Obitsu River Mouth Tidal Flat, Japan. They showed that benthic diatoms were some of the major components of the diets of two suspension feeding bivalves, $R$. philippinarum and $M$. veneriformis. The importance of the microphytobenthos as a food resource for the benthic suspension feeders has been clarified using isotopic techniques (e.g. Kang et al. 1999; Sauriau \& Kang 2000). Sauriau \& Kang (2000) estimated that approximately $70 \%$ of the annual secondary production of a bivalve, Cerastoderma edule, was supported by the microphytobenthos. Montani (1999) described the carbon flow from the microphytobenthos to $R$. philippinarum, the most dominant species of the macrobenthic animals, in the Seto Inland Sea, Japan. He showed that the primary production by the microphytonbenthos $(584 \mathrm{~g}$ $\mathrm{C} / \mathrm{m}^{2} / \mathrm{yr}$ ) on the tidal flat was so high as to support the secondary production of $R$. philippinarum $(26.5 \mathrm{~g}$ $\mathrm{C} / \mathrm{m}^{2} / \mathrm{yr}$ ) at the same place on the tidal flat.

In this study, we tried to describe the carbon flow from the micophytobenthos to the benthic suspension feeders on the lower part of the tidal flat in Midori River Mouth Tidal Flat, where $R$. philipinarum, occurred densely. Tsutsumi et al. (2002) investigated the population dynamics of this species at an area (near Stn 13 and 14 of this study), on the lower part of the same tidal flat, estimated its secondary production as $93.6 \mathrm{~g} \mathrm{C} / \mathrm{m}^{2} / \mathrm{yr}$, and deduced that approximately $1,300 \mathrm{mg} \mathrm{C} / \mathrm{m}^{2} /$ day $(=470 \mathrm{~g}$ $\mathrm{C} / \mathrm{m}^{2} / \mathrm{yr}$ ) of the primary production was potentially needed to support the secondary production of the clam under an assumption of the trophic transfer efficiency from the primary producer to the secondary one as $20 \%$.

Since Tsutsumi et al. (2002) did not examine the concentration of Chl- $a$ of the surface sediment at that time, if we applied the mean concentration of Chl- $a$ of the surface sediment on the lower part of the tidal flat (28.3 mg Chl- $a / \mathrm{m}^{2}$ ) of this study to that of the study site of Tsutsumi et al. (2002), extremely high Chl-a specific productivity by the microphytobenthos $(46 \mathrm{mg} \mathrm{C} /$ mg Chl-a/day) was required to satisfy the potential requirement of the primary production by the secondary production of $R$. philipinarum. This value is, however, not realistic, since it is equivalent to approximately three times that of primary productivity on a sand flat in the Seto Inland Sea, Japan, $16.5 \mathrm{mg} \mathrm{C/mg} \mathrm{Chl-a/day} \mathrm{(Mon-}$ tani et al., 2003). Many other previous studies also reported much lower Chl- $a$ specific productivity of the microphytobenthos (3.3 and $26.0 \mathrm{mg} \mathrm{C} / \mathrm{mg} \mathrm{Chl-a/day)} \mathrm{than}$ our estimate (De Jong \& de Jong 1995; Coligin \& de Jong 1984; Pinkney \& Zingmark 1991; Schreiber \& Pennock 1995; MacIntyre \& Cullen 1996). The Chl- $a$ concentration of the sediment was not so high (19.3 to $35.3 \mathrm{mg} / \mathrm{m}^{2}$ ) on the tidal flat (Fig. 5(a)). According to the results on the Chl- $a$ specific productivity obtained from the previous studies, the secondary production of the dense patches of $R$. philippinarum and $M$. veneriformis on the lower part of the tidal flat in this study is not fully supported by the primary production on the same area of the tidal flat.

In this study, we did not measure the phytoplanktonic biomass of the overlying water column. Our follow up study found that the annual mean Chl- $a$ concentration of the water column on the lower part of the tidal flat during the flood tide in spring tide was only $12.1 \mathrm{mgChl}$-al $\mathrm{m}^{2}$ (unpublished data). Therefore, both of the primary 


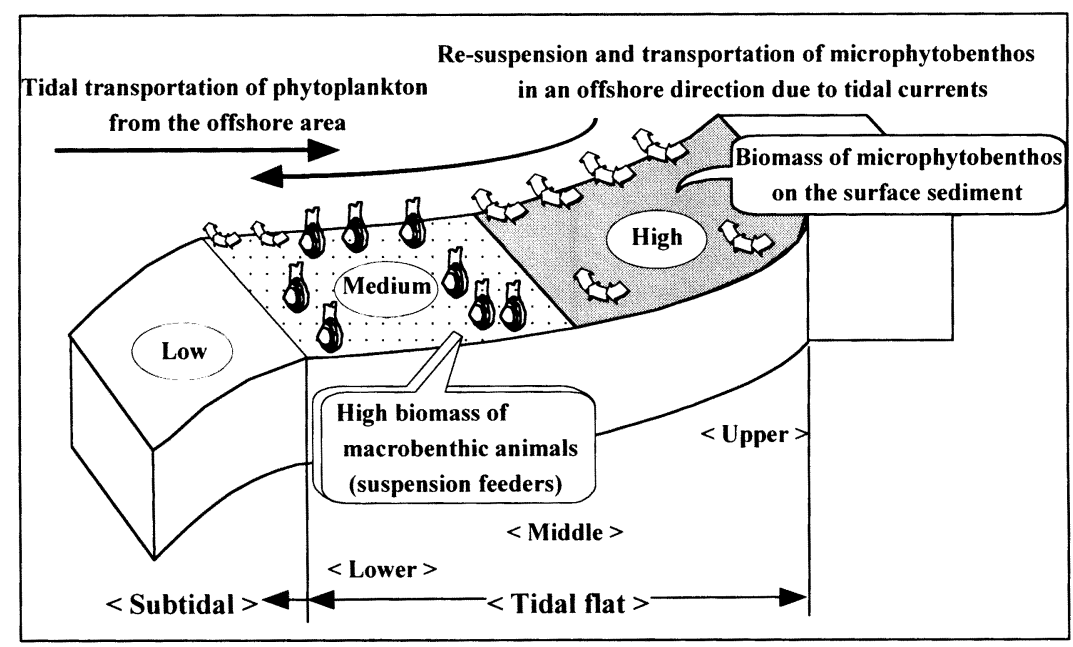

Fig. 7. A schematic diagram indicates the relationship between high primary production by the microphytobenthos on the upper part and high secondary production by suspension feeding bivalves on the middle to lower part of the tidal flat.

production by the phytoplankton in the overlying water and by the microphytobenthos on the surface sediment should be too short to support the high secondary production from the dense patches of the suspension feeding clams on the middle to lower part of the tidal flat.

In this study, the place where the microphytobenthos grew thickly on the sediment surface was restricted on the upper part of the tidal flat (Fig. 5(a)), and the microphytobenthos was easily re-suspended to the overlying water by the tidal current, waves and so on (e.g. Schffer \& Sullivan 1988; Lucas et al. 2001). As shown in the schematic diagram in Fig. 7, it is very likely that the resuspension of microphytobenthos to the water on the upper part of the tidal flat and its transportation toward the offshore area by the tidal current allow the suspension feeding bivalves to establish dense patches on the on the middle to lower part of the tidal flat.

We will continue the ecological studies on this tidal flat to clarify how many organic particles are produced by the primary production of the microphytobenthos on the sediment and the phytoplankton in the water in each part of Midori River Estuary, and how many organic particles are passing through from the upper to lower part of the tidal flat. We will report the results of these studies elsewhere.

Acknowledgements. The sampling was conducted by obtaining the cooperation of Kawaguchi Fishery Cooperative Society. We would like to express our thanks to Mr. Hisashi Shibata, Ms. Emiko Okamura and the undergraduate students of Faculty of Environmental and Symbiotic Sciences, Prefectural University of Kumamoto, for helping with the field sampling. This work was supported by a Grant-in-Aid for Scientific Research of the Ministry of Education, Culture, Sports, Science and Technology, Japan (No. 15201001) and a grant for the regional research of Prefectural University of Kumamoto.

\section{REFERENCES}

Akiyama, A and M. Matsuda (eds.) 1974. The handbook of tidal flat animals. Toyo-Kan Press, Tokyo, 332 pp. (in Japanese)

Colijin, F. and V. N. de Jonge 1984. Primary production of microphytobenthos in the Ems-Dollard Estuary. Marine Ecology Progress Series, 14: 185-196.

Conover, R. J. and R. Durvasula 1986. Probable loss of chlorophyll-derived pigments during passage through the gut of zooplankton, and some of the consequences. Limnology and Oceanography, 31: 878-887.

de Jonge, D. J. and V. N. de Jonge 1995. Dynamics and distribution of microphytobenthic chrolophyll- $a$ in the Western Scheldt estuary (SW Netherlands). Hydrobiologia, 311: 2130.

Environment Agency, Japan (ed.) 1994. The 4th basic survey for the conservation of the natural environment. Report on the coastal fauna and environment (Surveys on the tidal flat, algal bed a coral reef). Vol. 1, Tidal flat, $291 \mathrm{pp}$. (in Japanese)

Graf, G., W. Bengtsson, U. Diesner, R. Schulz and H. Theede 1982. Benthic response to sedimentation of a spring phytoplankton bloom: process and budget. Marine Biology, 67: 201-208.

Graf, G. 1992. Benthic-pelagic coupling: A benthic view. Oceanography and Marine Biology: an Annual Review, 30: 149-190.

Heip, C. H. R., N. K. Goosen, P. M. J. Herman, J. Kromkamp, J. J. Middelburg and K. Soetaert 1995. Production and consumption of biological particles in temperate tidal estuaries. Oceanography and Marine Biology: an Annual Review, 33: 
rately between $C$. soyoae and $C$. okutanii based solely on the shell length-height ratio because the ratios of the species overlap. The overlap may be due to growth-related changes in shell shape. To detect the species composition accurately, molecular analysis (or more stable key characteristics for classification) will be needed.

Most ecological studies of the genus Calyptogena in Sagami Bay have been conducted at the OHI cold-seepage site; reports have provided descriptions of the habitat and colonies (Okutani \& Egawa 1985; Hashimoto et al. 1989, 1995) and lifehistory characteristics such as growth, metamorphosis (Horikoshi \& Hashimoto 1992; Hattori et al. 1993), and reproduction (Momma et al. 1995; Fujiwara et al. 1998). In these studies, all Calyptogena species from $\mathrm{OHI}$ were treated as $C$. soyoae. According to our data, however, $74.4 \%$ of the Calyptogena species at $\mathrm{OHI}$ are $C$. okutanii (Table 2). Therefore, most of the ecological information on the Calyptogena species in Sagami Bay has been derived almost exclusively from C. okutanii. In contrast, ecological information on Calyptogena from SK has been derived predominantly from $C$. soyoae, given that more than $90 \%$ of the Calyptogena at this site are C. soyoae (Hattori et al. 1993).

In conclusion, the species composition of Calyptogena in Sagami Bay differed from that in the local coldseepage areas; the dominant species of Calyptogena at $\mathrm{OHI}$ and $\mathrm{OB}$ was $C$. okutanii, and that at SK was $C$. soyoae. Ecological information on Calyptogena in Sagami Bay is derived predominantly from C. okutanii, given that most ecological studies have been conducted at OHI. To determine the causes of differences in species composition among cold-seepage areas, additional field surveys are needed, especially at SK.

Acknowledgments. I am grateful to the operating teams of the Shinkai 2000, Shinkai 6500, and Dolphin $3 K$ submersibles and to the officers and crew of the tender ships Natsushima and Yokosuka of the Japan Marine Science and Technology Center (JAMSTEC) for their help in collecting samples. I thank Dr. Hashimoto for his kind advice, suggestions, and critical reading of the manuscript. I also thank Drs. S. Kojima, J. Fujikura, and Y. Fujiwara for their kind advice and suggestions. Ms. $\mathrm{H}$. Nakamura, E. Suzuki, and K. Yamamoto provided a great deal of help with the maintenance of specimens.

\section{REFERENCES}

Barry, J. P., R. E. Kochevar and C. H. Baxter 1997. The influence of pore-water chemistry and physiology on the distribu- tion of vesicomyid clams at cold seeps in Monterey Bay: implications for patterns of chemosynthetic community organization. Limnology and Oceanography, 42: 318-328.

Endow, K. and S. Ohta 1990. Occurrence of bacteria in the primary oocytes of vesicomyid clam Calyptogena soyoae. Marine Ecology Progress Series, 64: 309-311.

Fujiwara, Y., J. Tsukahara, J. Hashimoto and K. Fujikura 1998. In situ spawning of a deep-sea vesicomyid clam: evidence for an environmental cue. Deep-Sea Research I, 45: 18811889.

Hashimoto, J., S. Matsuzawa and H. Hotta 1988. Searching for biological communities at the Okinoyama Bank Site, the Sagami Bay. Proceedings of JAMSTEC Symposium on Deep Sea Research, 4: 177-188. (in Japanese with English abstract)

Hashimoto, J., S. Ohta, K. Fujikura, Y. Fujiwara and S. Sukizaki 1995 Life habit of vesicomyid clam, Calyptogena soyoae, and hydrogen sulfide concentration in interstitial waters in Sagami Bay, Japan. Journal of Oceanography, 51: $341-350$

Hashimoto, J., S. Ohta, T. Tanaka, H. Hotta, S. Matsuzawa and H. Sakai 1989. Deep-sea communities dominated by the giant clam, Calyptogena soyoae, along with slope foot of Hatsushima Island, Sagami Bay, central Japan. Palaeogeography, Palaeoclimatology, Palaeoecology, 71: 179-192.

Hattori, M., Y. Kanie, J. Hashimoto and K. Fujikura 1993. Geological settings, mode of life and morphology of genus $\mathrm{Ca}$ lyptogena along the subduction zone of the Sagami and Suruga Troughs, central Japan. Proceedings of JAMSTEC Symposium on Deep Sea Research, 9: 237-251. (in Japanese with English abstract)

Horikoshi, M. and J. Hashimoto 1992. Two distinct growth stages of a deep-sea, giant white clam, "Calyptogena" soyoae, and its allied species. Extrait de La Mer, 30: 73-82.

Kojima, S. 2002. Deep-sea chemoautosynthesis-based communities in the northwestern Pacific. Journal of Oceanography, 58: 343-363.

Kojima, S., J. Hashimoto and S. Ohta 1995a The distribution and the phylogenies of the species of genus Calyptogena and those of vestimentiferans around Japan. JAMSTEC Journal of Deep-Sea Research, 11: 243-248. (in Japanese with English abstract)

Kojima, S., R. Segawa, T. Kobayashi, T. Hashimoto, K. Fujikura, J. Hashimoto and S. Ohta 1995b. Phylogenetic relationships among species of Calyptogena (Bivalvia: Vesicomyidae) collected around Japan revealed by nucleotide sequences of mitochondrial genes. Marine Biology, 122: 401407.

Kojima, S. and S. Ohta 1997a. Bathymetrical distribution of the species of the genus Calyptogena in the Nankai Trough, Japan. Venus, 56: 293-297.

Kojima, S. and S. Ohta 1997b. Calyptogena okutanii n. sp., a sibling species of Calyptogena soyoae Okutani, 1957 (Bivalvia: Vesicomyidae). Venus, the Japanese Journal of Malacology, 56: 189-195.

Lisin, S. E., E. E. Hannan, R. E. Kochevar, C. Harrold and J. P. Barry 1997. Temporal variation in gametogenetic cycles of vesicomyid clams. Invertebrate Reproduction and Develop- 


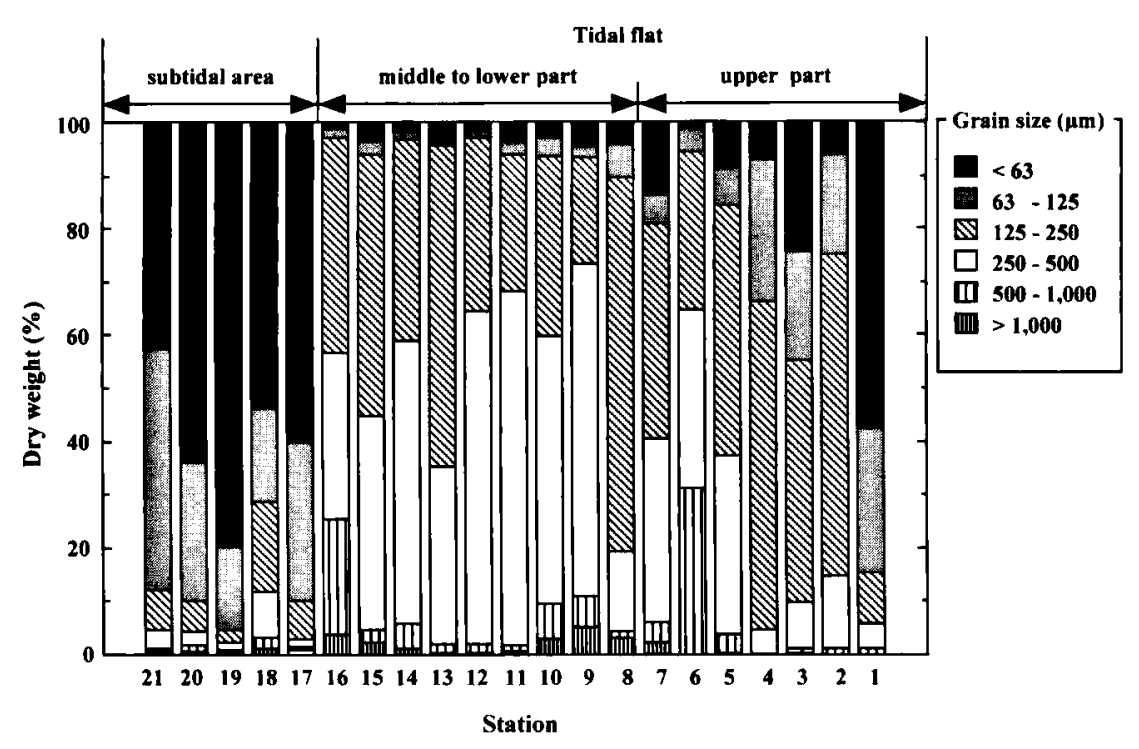

Fig. 2. Particle size composition of the sediment at each station.

sediment tended to markedly decrease toward the lower end of the tidal flat (Stn 16). On the middle to lower part of the tidal flat, the sediment contained only 2.8 to $10.5 \%$ of these two fractions, respectively. The sediment of this area was mainly consisted of fine sand (125 to $250 \mu \mathrm{m}$ in diameter) and medium sand ( 250 to $500 \mu \mathrm{m}$ in diameter), 71.7 to $94.9 \%$ of the weight of the whole sediment. At the subtidal area, the contents of the mud and very fine sand drastically increased again. These two fractions occupied 71.4 to $95.4 \%$ of the weight of the whole sediment.

Chemical composition of organic matter of the sediment

Fig. 3 shows the relationship between the percentage of the mud and very fine sand in the weight of the whole sediment and the organic matter content of the sediment with (a) TOC and (b) TN. Significant positive correlations were found in both of these two relationships (a: $F$ test, $p<0.001, b$ : $F$ test, $p<0.001$ ). The sediment with higher content of the mud and very fine sand tended to retain higher organic matter content.

Fig. 4 illustrates the contents of TOC and TN of the sediment at each sampling station. These values reflected well the contents of the fine particles of the sediment at each station (Fig. 3). As the fractions of the mud and very fine sand of the sediment markedly decreased from the upper part to the lower part of the tidal flat, the contents of TOC and TN of the sediment also decreased. The mean contents of TOC and TN of the sediment on the upper part of the tidal flat was $3.41 \pm 2.50 \mathrm{mg} / \mathrm{g}$
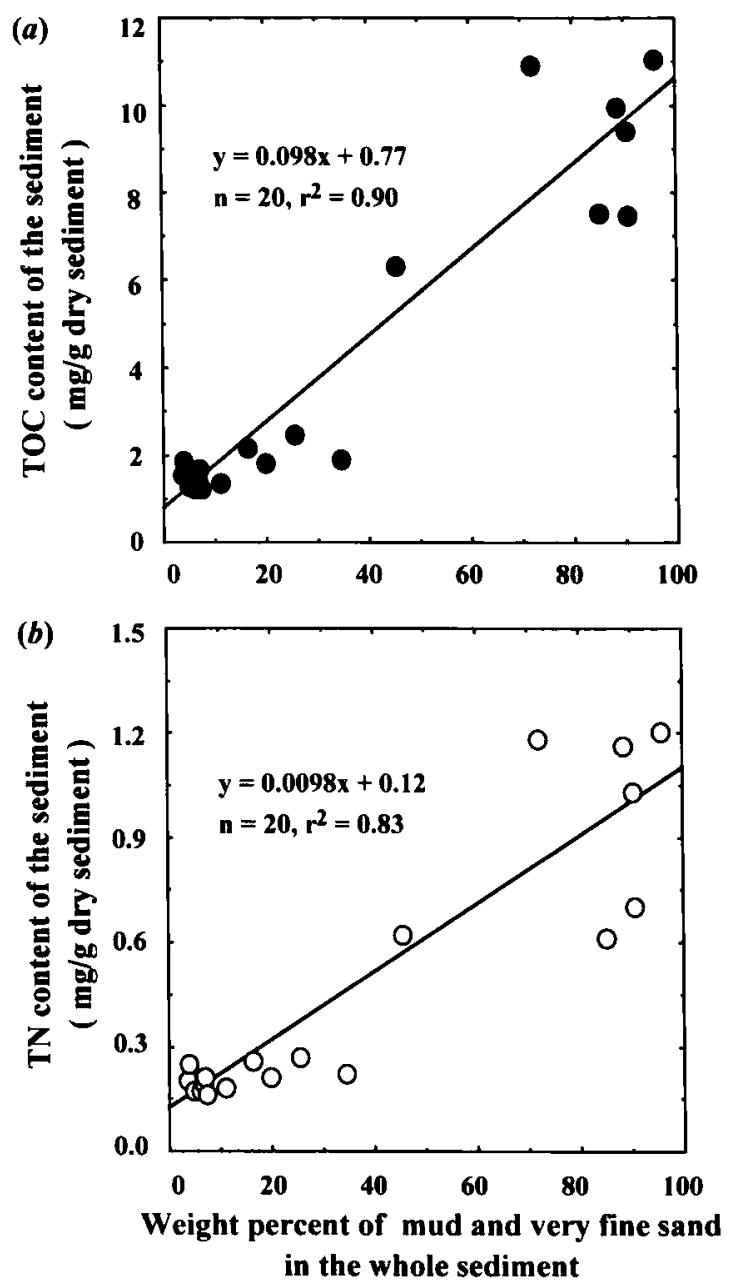

Fig. 3. The relationship between the proportions of mud and very fine sand (the particles finer than $125 \mu \mathrm{m}$ in diameter) in the whole sediment and (a) TOC content of the sediment and (b) TN content of the sediment. 

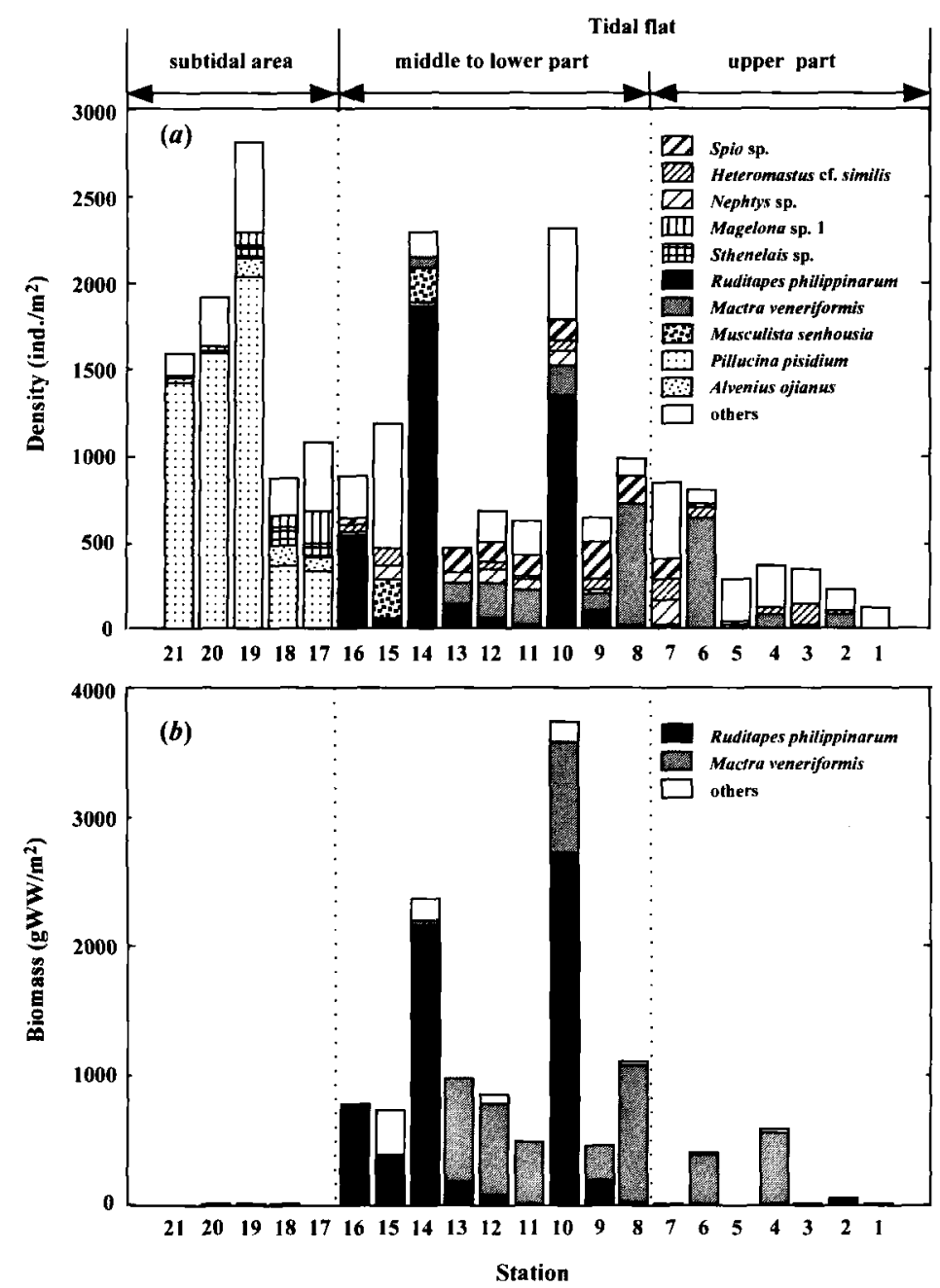

Fig. 6. (a) Density and (b) biomass of the macrobenthic animals at each station.

total biomass on this part of the tidal flat and $93.2 \%$ of the total biomass at all sampling stations. At the subtidal area, in spite of the occurrence of a bivalve, $P$. pisidium, in high densities $\left(330-2,030\right.$ ind. $\left./ \mathrm{m}^{2}\right)$, the total biomass of the macrobenthic animals was extremely low (4.4 to $11.6 \mathrm{~g} \mathrm{WW}^{2} / \mathrm{m}^{2}$ ). Consequently, $92.0 \%$ of the biomass of the macrobenthic animals collected from all sampling stations in Midori River estuary was concentrated on the middle to lower part of the tidal flat.

\section{DISCUSSION}

\section{Spatial difference of the physico-chemical character- istics of the sediment}

The particle size composition of the sediment showed a clear spatial gradient (Fig. 2). The fractions of the mud and very fine sand (finer than $125 \mu \mathrm{m}$ in diameter) in the total sediment markedly decreased from the upper end (Stn 1,84.5\%) to lower end of the tidal flat (Stn 16, 2.8\%). On the other hand, these two fractions occupied high proportions at the subtidal area (Stn $17-21,71.4-95.4 \%$ ) such as Stn 1 located on the uppermost areas of the tidal flat. There was a significant positive relationship between the fractions of the fine particles of less than $125 \mu \mathrm{m}$ in diameter and TOC and TN contents of the sediment (Fig. 3). Consequently, the organic matter content of the sediment showed a clear spatial distribution pattern as the fraction of the mud and very fine sand of the sediment (Fig. 4).

Such distribution patterns of the fine particles and the organic matter content of the sediment area offshore from the tidal flat are caused by deposition of the sediment supplied from the river on the tidal flat, re-suspension of only the fine particles with high organic matter content and lateral transportation of the fine particles to the upper part of the tidal flat and to the subtidal area offshore from the tidal flat by the tidal current (Saijyo \& 
$1-149$

Herman, P. M. J., J. J. Middelburg, J. van de Kippel and C. H. R. Hcip 1999. Ecology of estuarine macrobenthos. Advances in Ecological Research, 29: 195-240.

Kang, C. K., P.-G. Sauriau, P. Richard and G. F. Blanchard 1999. Food sources of the infunal suspension-feeding bivalve Cerastoderma edule in a muddy sandflat of Marennes-Oleron Bay, as determined by analyses of carbon and nitrogen stable isotopes. Marine Ecology Progress Series, 187: 147-158.

Kimata, M., A. Kawai and Y. Ishida 1960. The method for sampling of marine bottom muds. Bulletin of the Japanese Society of Scientific Fisheries 26: 1227-1230. (in Japanese with English abstract)

Koike, H., Nakajima, T. and N. Nakai 1989. Stable carbon isotopic and gut content analyses of a tidal flat food web. Benthos Research 37: 1-10. (in Japanese with English abstract)

Loo, L. and R. Rosenberg 1988. Bivalve suspension-feeding dynamics and benthic-pelagic coupling in an eutrophicated marine bay. Journal of Experimental Marine Biology and Ecology: 130: 253-276.

Loo, L. and R. Rosenberg 1996. Production and energy budget in marine suspension feeding populations: Mytilus edulis, Cerastoderma edule, Mya arenaria and Amphiura filiformis. Journal of Sea Research, 35: 199-2(07.

Lucas, C. H., C. Banham and P. M. Holligan 2001. Benthicpelagic exchange of microalgae at a tidal flat. 2. Taxonomic analysis. Marine Ecology Progress Series, 212: 39-52.

MacIntyre, H. L. R. J. Geider and D. G. Miller 1996. Microphytobenthos: The ecological role of the "secret garden" of unvegetated, shallow-water marine habitats. I. Distribution, abundance and primary production. Estuaries, 19: 186-201.

MacIntyre, H. L. and J. J. Cullen 1996. Primary production by suspended and benthic microalgae in a turbid estuary: timescales of variability in San Antonio Bay, Texas. Marine Ecology Progress Series, 145: 245-268.

Montani, S. 1999. Nutrient and particle dynamics in a coastal shallow waters-A link between the intertidal and the subtidal zones-. Journal of Japan Society on Water Environment, 22: 533-538 (in Japanese).

Montani, S., P. Magni and N. Abe 2003. Seasonal and interannual patterns of intertidal microphytobenthos in combination with laboratory and areal production estimates. Marine Ecology Progress Series, 249: 79-91.

Nagao, N., Toda, T., K. Takahashi, K.Hamazaki, T. Kikuchi and S. Taguchi 2000. High ash content in net-plankton samples from shallow coastal water: possible source of error in dry weight measurement of zooplankton. Journal of
Oceanography, 57: 105-107.

Pinckney, J. and R. G. Zingmark 1991. Effects of tidal stage and sun angles on intertidal benthic microalgal productivity. Marine Ecology Progress Series, 76: 81-89.

Ryther, J. H. 1969. Photosynthesis and fish production in the sea. Science, 166: 72-76.

Saijyo, Y. and S. Okuda 1996. Tidal Rivers-their natural state and human induced changes. Nagoya-University Press, Nagoya, pp. 85-105. (in Japanese)

Sasaki, K. 1994. Material circulation and production in estuary and tidal flat $8-$ material circulation on tidal flats. Aquabiology, 16: 122-128. (in Japanese)

Sauriau, P.-G. and C. K. Kang 2000. Stable isotopic evidence of benthic microalgae-based growth and secondary production in the suspension feeder Cerastoderma edule (Mollusca, Bivalvia) in the Marennes-Oleron Bay. Hydrobiologia, 440: 317-329.

Schreiber, R. A. and J. P. Pennock 1995. The relative contribution of benthic microalgae to total microalgal production in a shallow sub-tidal estuarine environment. Ophelia, 42: 335352.

Shaffer, G. P. and M. J. Sullivan 1988. Water column productivity attributable to displaced benthic diatoms in well-mixed shallow estuaries. Journal of Phycology, 24: 132-140.

Thompson, M. L. and L. C. Schaffiner 2001. Population biology and secondary production of the suspension feeding polychaete Chaetopterus cf. variopedatus: implications for benthic-pelagic coupling in lower Chesapeake Bay. Limnology and Oceanography, 46: 1899-1907.

Tsutsumi, H., T. Takeguchi, W. Maruyama and T. Nakahara 2000. Seasonal fluctuations in the benthic community after the collapse of a clam, Ruditapes philippinarum, population on the Midorikawa River tidal flats in Kumamoto. Japanese Journal of Benthology, 55: 1-8. (in Japanese with English abstract)

Tsutsumi, H., K. Ishizawa, M. Tomishige, K. Sakamoto and S. Montani 2002. Population dynamics of a clam, Ruditapes philippinarum, on an artificially created sand cover on the tidal flats at river mouth of Midorikawa River. Japanese Journal of Benthology, 57: 177-187. (in Japanese with English abstract)

Underwood, G. J. C. and J. Kromkamp 1999. Primary production by phytoplankton and microphytobenthos in estuaries. Advances in Ecological Research, 29: 93-153.

Yentsch, C. S. and D. W. Menzel 1963. A method for the determination of phytoplankton chlorophyll and phacophytin by fluorescence. Deep-Sea Research, 10: 221-231. 
Appendix Table 1. Numerical composition of the macrobenthic animals at each station (ind./0.05 $\mathrm{m}^{2}$ ). Alphabetical symbols next to the species names indicate taxonomic groups (Bi: Bivalvia, Po: Polychaeta).

\begin{tabular}{|c|c|c|c|c|c|c|c|c|c|c|c|c|c|c|c|c|c|c|c|c|c|c|c|c|}
\hline & Species & Stn & 1 & 2 & 3 & 4 & 5 & 6 & 7 & 8 & 9 & 101 & 111 & 121 & 13 & 1415 & 161 & 171 & 18 & 192 & 202 & 21 & Total & $\begin{array}{c}\text { Cumulative } \\
\text { percent }\end{array}$ \\
\hline 1. $\mathrm{Bi}$ & Pillucina pisidium & & 0 & 0 & 0 & 0 & 0 & 0 & 0 & 0 & 0 & 0 & 0 & 0 & 0 & 0 & 01 & 171 & 18 & 1027 & 797 & 71 & 287 & 27.0 \\
\hline 2. $\mathrm{Bi}$ & Ruditapes philippinarum & & 0 & 0 & 0 & 0 & 0 & 0 & 0 & 1 & 5 & 67 & 1 & 3 & 7 & 93 & 27 & 0 & 0 & 0 & 0 & 0 & 207 & 46.5 \\
\hline 3. $\mathrm{Bi}$ & Mactra veneriformis & & 0 & 4 & 1 & 4 & 03 & 32 & 13 & 35 & 5 & 91 & 101 & 10 & 6 & 1 & 0 & 0 & 0 & 0 & 0 & 0 & 118 & 57.7 \\
\hline 4. Po & Spio sp. & & 0 & 0 & 0 & 0 & 1 & 1 & 6 & 8 & 11 & 6 & 6 & 6 & 7 & 0 & 2 & 0 & 0 & 0 & 0 & 0 & 54 & 62.3 \\
\hline 5. Po & Hetromastus cf. similis & & 0 & 1 & 6 & 2 & 1 & 3 & 6 & 0 & 3 & 3 & 1 & 2 & 0 & 0 & 2 & 0 & 0 & 1 & 0 & 0 & 36 & 66.1 \\
\hline 6. Po & Nephtys sp. & & 0 & 0 & 0 & 0 & 0 & 0 & 7 & 0 & 1 & 4 & 3 & 4 & 3 & 34 & 1 & 0 & 0 & 1 & 0 & 0 & 31 & 69.0 \\
\hline 7. $\mathrm{Bi}$ & Musculista senhousia & & 0 & 0 & 0 & 0 & 0 & 0 & 0 & 0 & 0 & 0 & 0 & 0 & 0 & 1011 & 0 & 0 & 0 & 0 & 0 & 0 & 21 & 71.0 \\
\hline 8. Po & Magelona sp. 1 & & 0 & 0 & 0 & 0 & 0 & 0 & 0 & 0 & 0 & 0 & 0 & 0 & 0 & $\begin{array}{ll}0 & 0\end{array}$ & 01 & 10 & 3 & 4 & 0 & 1 & 17 & 72.6 \\
\hline 9. Po & Sthenelais sp. & & 0 & 0 & 0 & 0 & 0 & 0 & 0 & 0 & 0 & 0 & 0 & 0 & 0 & 0 & 0 & 4 & 6 & 4 & 1 & 1 & 16 & 74.1 \\
\hline \multirow[t]{3}{*}{ 10. $\mathrm{Bi}$} & Alvenius ojianus & & 0 & 0 & 0 & 0 & 0 & 0 & 0 & 0 & 0 & 0 & 0 & 0 & 0 & $\begin{array}{ll}0 & 0\end{array}$ & 0 & 4 & 5 & 5 & 1 & 0 & 15 & 75.5 \\
\hline & Others & & 6 & 6 & 10 & 121 & 12 & 42 & 22 & 5 & 7 & 261 & 10 & 9 & 0 & 736 & 122 & 201 & 11 & 251 & 14 & 6 & 260 & \\
\hline & Total & & 6 & 11 & 17 & 181 & 144 & 40 & 424 & 493 & 32 & 1153 & 313 & 342 & 23 & 11459 & 445 & 544 & 43 & 1419 & 957 & 79 & 1061 & 100.0 \\
\hline
\end{tabular}

